Please cite as:

Cheng, M., Wong, A., \& Prideaux, B. (2016). Political Travel Constraint: The Role of Chinese Popular Nationalism. Journal of Travel \& Tourism Marketing.

DOI: $10.1080 / 10548408.2016 .1182456$

Video Link:

https://www.youtube.com/watch?v=7wdyvu59j6M

\title{
Political Travel Constraint: The Role of Chinese Popular Nationalism
}

\author{
Mingming Cheng* \\ University of Technology Sydney, Australia \\ Anthony Ipkin Wong \\ City University of Macau, China \\ Bruce Prideaux \\ Central Queensland University, Australia
}




\title{
Political Travel Constraint: The Role of Chinese Popular Nationalism
}

\begin{abstract}
This study conceptualized a new type of political travel constraint by examining the role that popular nationalism has on Chinese outbound travel. Using a case study approach based on the 2012 Diaoyu/Senkaku Island Incident between China and Japan, the study demonstrates how Chinese popular nationalism has the potential to shape the geopolitical environment of all outbound Chinese tourism. The study proposes a new model that can be used to illustrate how popular nationalism may affect bilateral tourism in other settings. Findings of this study offer important insights for both scholars and practitioners in understanding the impact of Chinese popular nationalism on bilateral tourist flows.
\end{abstract}

Keywords: Popular nationalism, travel constraint, Chinese outbound tourists, Japan, tourist flow

\section{Introduction}

Researchers have identified a number of factors that drive tourists' decision making and behaviors. One group of researchers has focused on the role of motives (Crompton, 1979; Iso-Aloha, 1982; Pearce \& Lee, 2005). Other studies have focused on travel constraints, many of which have adopted the leisure constraint model first advanced by Crawford and Godbey (1987) who proposed the model in an attempt to address the problem of leisure barriers by examining interactions between the person and their social and physical environment. Recent applications of the leisure constraint model in a tourism context have focused on personal (or intrinsic), interpersonal (or interactional) and structural constraints 
(or environmental) (Lee, Agarwal, \& Kim, 2012; Nyaupane \& Andereck, 2008; Zhang, Zhang, Cheng, Lu, \& Shi, 2012). Yet there are limitations to the application of the leisure constraint model when used in a travel context because constraints on travel tend to be viewed within a Western paradigm that as Dong \& Chick (2012, p.417) observed centers on 'Western, Educated, Industrialized, Rich and Democratic' society'. This may ignore non-Western political and cultural dimensions. As a consequence, research on the linkage between political ideology and its influence on tourist decisions and behaviors is seldom reported in the literature, despite evidence of the potential for political tensions to affect travel demand (Kim \& Prideaux, 2012). The lack of research on political travel constraints has limited our understanding of the reasons why tourists avoid travelling to some countries and in particular how constraints of this type may affect tourist decision making at different points in time such as during or after a crisis event.

Evidence from China indicates that major international political disruptions affecting bilateral relations often have a flow-on effect on Chinese consumers and their travel behaviors. In a recent example, a 2014 South China Sea dispute with the Philippines resulted in a 50\% declined in travel to the Philippines between September 2014 and April 2015 (Philippines Department of Tourism, 2015). In a similar manner, the 2012 Diaoyu/Senkaku Island Incident between China and Japan resulted in a fall of nearly $40 \%$ of Chinese visitors to Japan (Japan National Tourism Organization, 2014) (Table 1) after the incident. Given the size of China's outbound market, it is important to note that current studies on Chinese outbound tourists are particularly positive about its rapid and largely uninterrupted growth and failed to recognize the complicated socio-cultural and political realities of tourist flows. As such, this study challenges the normative economic excitement of the uninterrupted growing nature of outbound Chinese tourists and offers a different perspective on Chinese outbound tourists. Particularly, it highlights the political dimension of 
China's outbound tourism from a grassroots level and uncovers Chinese popular nationalism as a political travel constraint for Chinese tourists that enriches the existing studies on constraints of Chinese outbound travel (Li, Zhang, Mao, \& Deng, 2011; Sparks \& Pan, 2009; Zhou, King, \& Turner, 1998) by introducing political factors as a specific travel constraint.

From a boarder theoretical lens on studies concerning tourist flows, this study moves beyond the predominant normative economic models based on economic variables such as relative price, income or exchange rate in understanding tourist flows. It has acknowledged the political realities between two formerly hostile nations to identify underlying factors that may affect tourist flows. More importantly, as suggested by Timothy and Kim (2015), tourist flows may be volatile and fluctuate based on fluid variables that changes from time to time. Chinese popular nationalism stems in part from Chinese consumers' increasing knowledge about the West, their perceptions of unfair treatment by Western countries in the past, and more recently national pride in China's emergence as a global economic power (Zhao, 2004). Given the growing size of Chinese outbound market as a percentage of global tourist flows and the potential for deterioration in political relations to adversely affect tourist flows, an understanding of the implications of Chinese popular nationalism is becoming more important and this helps us re-evaluate the ways Chinese outbound tourism has been understood (Cheng \& Wong, 2014).

This study aims to examine how popular nationalism has become an important political travel constraint in a Chinese context. This study draws upon the Diaoyu/Senkaku Incident to investigate the role that popular nationalism may have on Chinese outbound tourists' preferences and behaviors. The paper also proposes a descriptive model to illustrate the impact of Chinese popular nationalism on Chinese outbound tourists. The purpose of the model (Figure 1) is to illustrate the various elements that may collectively effect bilateral relations. The next section offers an overview of the relevant literature on destination choice, 
travel constraints and Chinese popular nationalism, and the background of the island dispute incident between Japan and China. A discussion of the research approaches employed in this study follows. Findings of this study are then presented and discussed, and the paper concludes with both theoretical and practical implications that go beyond this study.

\section{Literature Review}

The theoretical foundation of this study rests on several research streams pertaining to tourist decision-making and destination choice, travel constraints, and nationalism. The theoretical underpinnings and empirical evidence of these research areas help develop the research model presented in Figure 1. In particular, this study focuses on political travel constraints as a manifestation of popular nationalism (Gries, 2006; Huges, 2006; Zhao, 2005). The destination choice and decision making theories (Crompton, 1992; Um \& Crompton, 1990; Woodside \& Lysonski, 1989) also shape the conceptualization of this research in respect to how tourists elect to avoid and reject visiting a specific destination during a certain point in time. This tourist behavior highlights the role of situational factors in the destination choice theory.

\section{Destination Choice}

The body of the literature on tourist decision making often points to the importance of destination choice in shaping tourist final travel decision. The work of Crompton and colleague (Crompton, 1992; Um \& Crompton, 1990) assert that travel decision making has three primary stages which involve a sequence of choice sets. In the first stage, the tourist evokes an awareness set of destinations which he or she would then select for later consideration (evoked) as a set of choices, leading to the second stage of the process. The 
tourist finally reaches a decision on his/her next trip in the final stage of the process. Both external stimuli (e.g., the media, reference groups, and social pressures) and internal stimuli (e.g., personal characteristics, motives, values, and attitudes) may exercise extensive influence on the formation of destination choice sets during this process (Um \& Crompton, 1990; Woodside \& Lysonski, 1989; Woodside, Macdonald, \& Burford, 2004). For example, intrinsic motives such as a desire to seek novelty and relaxation may affect a tourist to consider an array of Asian and Polynesian destinations. Yet, the recent political turmoils and instability in the Middle East and some Asian regions (e.g., Thailand and Hong Kong) reported by the media and commonly discussed in the community may impose social pressure in the selection process, resulting in a limited number of places in Asia and Polynesian islands such as Singapore and Hawaii where political stability can be taken for granted.

The preceding discussion points to another important aspect in the consideration process: situational constraints (Um \& Crompton, 1990; Woodside \& Lysonski, 1989) such as the media and reference groups. Much of the destination choice and travel constraint literature focuses on tourist-related situational factors such as time, cost, and personal incidents, and largely ignored the role of political incidents in inhibiting tourist travel decisions (Nyaupane \& Andereck, 2008). However, recent empirical evidence indicates that the political situation of potential destinations may also affect tourist decision making (Karl, Reintinger, \& Schmude, 2015). Building on this view, this research moves beyond previous research to include consideration of political factors such as nationalism in the process of destination choice. 


\section{Travel constraints}

The standard discourse in the extant tourism literature describes travel constraints as factors that inhibit people's desire to travel; inhibits their ability to begin, maintain or increase their frequency of travel; and the subsequent negative effects this causes on the quality of travel (Cho, Bonn, \& Brymer, 2014; Hung \& Petrick, 2010). The terms "risks", "barriers" and "inhibitors" are sometimes interchangeable with travel constraints, as they have similar meanings. Travel constraint studies to date have been based primarily on the leisure constraint model (Crawford \& Godbey, 1987; Hubbard \& Mannell, 2001). The three dimensions of leisure constraints (intrapersonal, interpersonal and structural) suggested by Crawford and Godbey (1987) have had a significant impact on the understanding of factors that constrain travel activities. Intrapersonal constraints describe individual psychological states (such as anxiety, stress and depression) which are subject to change over a short time period and may lead to lower participation. Interpersonal constraints refer to the unavailability of other people, which usually occurs when people require at least one partner or they have a strong preference for a co-participant to participate in activities of interests. These types of constraints have a tendency to change across people's life stages and largely depend on family size and activity types. The structural constraints represent lack of money, opportunity, unavailability of time, inconvenient accessibility and inadequate information. These three type of constrains are argued to occur in a hierarchical manner. Crawford, Jackson, and Godbey (1991) argue that to maintain an individuals' impetus, they need to negotiate through "an alignment of multiple factors, arranged sequentially, that could be overcome, through these systematic level" (p.314). Indeed, evidence shows that tourist's final travel decision is a successful negotiation of most perceived or real constraints rather than absence of constraints (Chen, Chen, \& Okumus, 2013). If tourists' motivation traveling to a certain destination is strong enough, they might overcome certain constraints (Nyaupane \& 
Andereck, 2008), such as costs. For example, Fendt and Wilson (2012) argued that individuals can negotiate their travel constraints, such as social-cultural and practical constraints for women participating in surfing tourism, if they maintain a positive attitude, have better preparation, and are passionate about their travel activities.

While the leisure constraint model has been widely accepted and tested a number of times (He, Li, Harrill, \& Cardon, 2014; Lai, Li, \& Harrill, 2013), recent studies have identified a new range of travel constraints. Dong and Chick (2012), for example, argue that constraints constitute a cultural domain including items or ideas that members of a particular social group understand and regard as important and as a result affect attitudes towards travel. Chen et al. (2013) identified a new constraint dimension termed as 'unfamiliar cultural constraints' during a study of Taiwanese youth travellers' travel constraints to Brunei. Other researchers have also identified new sub dimensions under each specific constraint dimension. For example, Nyaupane and Andereck's (2008) study in Arizona found that the structural constraint dimension could be expanded to include the sub-dimensions of "place attributes", "cost" and "lack of time". Finally, in a study of Chinese outbound tourists' perceived constraints to visiting the United States, Lai et al. (2013) found that the "interpersonal" constraints dimension did not apply but rather two distinct sub-dimensional constraints ("lacking security" and "English language barriers") were important. Collectively, these findings suggest that the travel constrain model may not be universal and that tourists' cultural and political context may be an important indicator of attitudes to travel.

In general, the literature has tended to focus on political instability within tourist destinations (e.g. War) (Alvarez \& Campo, 2014) and government policy towards tourist flows (Prideaux, 2005), with less attention paid to tourist behaviour between previously hostile countries such as China and Japan. As a consequence, academics and practitioners 
still lack a detailed understanding of how political issues act as a travel constraint, and in the case of China, the role of Chinese popular nationalism.

\section{Chinese Popular Nationalism}

The concept of nationalism is subject to various theoretical interpretations and potentially negative connotations (Smith, 2001). At one end of the spectrum Blank \& Schmidt (2003, p. 293) state that 'Nationalism supports the nation in areas where there are authoritarian structures between the nation and its citizens, or where such structures are aspired to'. At the other end of the spectrum, the social psychological view of nationalism advocated by Kedourie (1993) suggests that nationalism is 'very much a matter of one's self-view, of one's estimation of oneself and one's place in the world' (p.141). For the purposes of this research and in the spirit of Kedourie (1993) approach, nationalism is defined broadly as the commitment to safeguard one's national identity. This approach also draws on Gries' (2006) view of nationalism which is understood as that aspect of an individual's self-concept that as the author notes, 'derives from his or her perceived membership in a national group' (p.490). It is important to note that nationalism is different from patriotism, which refers to an emotional attachment to a nation which an individual recognizes as their homeland and is usually coupled with national feeling or national pride (Kelman, 1997). Patriotism is not necessarily directed toward a nation state, whereas nationalism emphases the relationship of the individual to state in maintaining the state's independence, integrity and effective functioning (Kelman, 1997).

In contemporary China, two types of nationalism can be identified: "Chinese State Nationalism" and "Popular Nationalism" (Gries, 2006; Huges, 2006; Zhao, 2005). These are driven by two different forces. The former can be described as top down, organized and 
induced by the Chinese government. The latter is bottom up, and initiated by the Chinese people. Due to the anti-foreign tenor of Chinese popular nationalism, it appears to be largely the same as state nationalism and as such, many Western scholars have treated popular nationalists as puppets under the control of the Communist Party (Gries, 2006). However, popular nationalism has gradually strengthened its influence vis-à-vis state nationalism in recent years due to Chinese consumers' increasing knowledge about the West and their perceptions of unfair treatment of China by Western countries in the past, and more recently China's emergence as a global economic power beginning in the late 1990s (Zhao, 2004). Outbursts of popular nationalism are easily provoked by international events that seemingly insult China, especially by countries that have been hostile to China in the past. The accumulation of impacts does not come from the "accretion of evidence" but rather from its "symbolic value" (Birkland, 1997). That is, the interpretation of China's historical memory has created a framework against which the incident is viewed and this constantly modifies Chinese nationalist sentiments $(\mathrm{Li}, 2009)$. In respect to the political relationship between China and Japan, anti-Japan sentiments are particularly strong amongst the Chinese public because of both nations' contested history and contemporary political conflicts. One outcome of anti-Japanese sentiment has been massive anti-Japanese demonstrations across China (Huges, 2006).

Existing research directed towards building an understanding of Chinese popular nationalism has centered largely on its manifestation in conventional demonstrations against foreign products (Gao, 2012; Ishii, 2013) and increasing demands for political participation (Huges, 2006; Tang \& Darr, 2012). The 2012 Diaoyu/Senkaku island dispute was widely reported in the Chinese media on the rapid fall in Chinese outbound travel to Japan highlighting for the first time the role of popular nationalism in travel decision making. This research is a response to the clear research gap on this issue in the literature. Moreover, 
this research also illustrates the need for a deeper understanding of the theoretical linkage between political sciences and tourism (Matthews \& Richter, 1991) beyond the current approaches that mainly focus on policy analysis when analyzing international relationship on tourist flow (Timothy \& Kim, 2015).

\section{Research context}

Japan and China have a long record of political conflicts and uneasy diplomatic relations dating back to the nineteenth century during the Qing Dynasty. Japan's seizing of Russia's Chinese territories after the Russo-Japanese War of 1904/05 and further aggression in Manchuria in 1931 which later escalated into a full scale invasion and the deaths of millions of Chinese civilians and military personnel, has shaped Chinese views of Japan (Cui, 2012; Li, 2009). Recent incidents, such as the Japanese Prime Minister's contentious visits to the Yasukuni Shrine where a large number of executed World War Two Japanese war criminals are buried, and the Japanese government's constant reconstruction of history textbooks, has intensified political conflicts between the two countries (Tian \& Pasadeos, 2012). Collectively, this past uneven history has influenced Chinese views on contemporary political relations with Japan.

The Diaoyu/Senkaku islands dispute erupted after the Japanese government publicly expressed its intention to purchase these disputed islands from a private Japanese owner to diffuse its "territorial dispute" with China (Ministry of Foreign Affairs of the People's Republic of China, 2012). In September 2012, after direct but non-lethal confrontation between Chinese and Japanese coast guard and fishing vessels, anti-Japan sentiments grew rapidly and triggered the largest anti-Japanese protests across dozens of mainland cities since China and Japan normalised diplomatic relations in 1972 ( $\mathrm{Li} \& \mathrm{He}, 2012$; Spegele \& Nakamichi, 2012). Many Chinese demonstrated their nationalist sentiments through 
boycotting Japanese goods and services. Some protests turned violent with attacks on Japanese made cars, sacking of Japanese restaurants and demonstrators throwing rocks and eggs at the Japanese embassy (South China Morning Post, 2012). From the perspective of the broader literature, the action taken against Japan, travel to Japan and Japanese made products is a form of brand and product rejection, and even boycott (Lee, Motion, \& Conroy, 2009; Yuksel \& Mryteza, 2009), with Japan being perceived as the overarching brand that actions such as the boycott were aimed at. In this sense, the anti-consumption campaigns elevated personal travel decisions from a protest based on brands and products to a social phenomenon involving nationalism derived views on the propriety of travel.

Japan has been a long-time favourite holiday destination for Chinese tourists and around 20 percent of all international visitors to Japan are Chinese outbound tourists (Japan National Tourism Organization, 2014). As Table 1 highlights, there was a sharp decline in Chinese travel to Japan during the period of the dispute despite the fact that no travel warning was issued by the Chinese government, the Japanese Yen was depreciating against the Chinese RMB (Japan National Tourism Organization, 2014) and travel to other destinations was increasing (Park \& Han, 2012). In Japan, many inbound operators reported difficulties due to the decrease in the number of arrivals from Chinese visitors (Chiu, 2013). For this reason, the Diaoyu/Senkaku Islands dispute offers a timely case study on the manifestation of popular nationalism in a tourism context in contemporary China. 
Table 1: Monthly flow of Mainland Chinese tourists traveling to Japan in 2011 and 2012

\begin{tabular}{|c|c|c|c|}
\hline & \multicolumn{2}{|l|}{ Number of visitors } & \multirow{2}{*}{$\begin{array}{l}\text { Changes (\%) compared } \\
\text { to } 2011 \text { monthly }\end{array}$} \\
\hline & 2011 & 2012 & \\
\hline January & 99,131 & 136,665 & 37.9 \\
\hline February & 105,362 & 81,966 & -22.2 \\
\hline March & 62,450 & 129,302 & 107.0 \\
\hline April & 76,164 & 148,793 & 95.4 \\
\hline May & 58,603 & 112,152 & 91.4 \\
\hline June & 61,419 & 125,983 & 105.1 \\
\hline July & 86,963 & 204,270 & 134.9 \\
\hline August & 102,640 & 190,254 & 85.4 \\
\hline September & 112,493 & 121,673 & 8.2 \\
\hline October & 106,174 & 69,713 & -34.3 \\
\hline November & 92,154 & 51,993 & -43.6 \\
\hline December & 79,688 & 52,336 & -34.3 \\
\hline $\begin{array}{l}\text { Total for Chinese } \\
\text { visitors }\end{array}$ & $1,043,246(17 \%)$ & $1,425,100(18 \%)$ & \\
\hline $\begin{array}{l}\text { Total for Foreign } \\
\text { visitors to Japan }\end{array}$ & $6,218,752$ & $8,358,105$ & \\
\hline
\end{tabular}

\section{Methodology}

Based on the previous discussion we postulate that Chinese popular nationalism has emerged as a new form of political travel constraint that has the potential to negatively influence Chinese tourists' attitudes and travel intentions towards Japan. To gain insights into how political tensions of this nature that exist between China and Japan affect travel decisions, an 
inductive approach was adopted using a qualitative interpretative paradigm, as existing studies in travel constraints are mostly based on quantitative approach and have failed to provide a detailed understanding of the constraints, negotiation strategies, and contexts in which the dynamics of constraint-negotiation process occurs (Mannell, Iwasaki, \& Jackson, 2005). Data was collected using semi-structured in-depth interviews. The rationale for choosing an interpretivist approach was to enable participants' voices to be heard, to explore 'embedded meaning' and to discover reasons for observed behaviour (Huberman, 2003).

The respondents were selected based on purposeful sampling of Shanghai residents who delayed or abandoned their trips to Japan. Selection of this group enabled the researchers to identify a range of travel attitudes and further behavioral changes that had not been previously identified in the literature. The lead researcher recruited 25 volunteers with an almost equal number of males and females ranging in age from 23 to 56 years from one of the largest outbound Chinese travel agencies in Shanghai with the assistance of one of the company managers. In all eight persons declined to participate. Two semi-structured interviews were conducted with each informant in a place of the informants' choices. The rationale for choosing Shanghai as the research context were twofold: 1) despite Shanghai being attacked by Japan in World War II, Japan has long been ranked as the most popular travel destination for Shanghai residents; 2) tourists from Shanghai account for a large proportion of Chinese visitors to Japan (World Travel Online, 2012) but the number of visitors to Japan dropped significantly during the period of the dispute (Japan National Tourism Organization, 2014).

The lead researcher is a native Mainland Chinese citizen which aids deeper and richer insights into the respondents' views because of the sensitive nature and potential embarrassment of the interview process (Strauss \& Corbin, 1990). The first interview took 
place during the most severe period of diplomatic tensions. The interview questions focus on respondents' decisions to delay or cancel their trip to Japan. The second interview with the same informants was conducted three months later, when Chinese outbound tourism to Japan had resumed (Japan National Tourism Organization, 2014). In the second interview informants were asked about their future intention to visit Japan and the reasons for doing so. The rationale of this approach was to understand the incident's impacts on Chinese tourists' views over the duration of the tension.

During the interview, the lead author introduced himself to each informant, outlined the purpose of this research and gained written consent to proceed with the interview questions. Pseudonym names were used to maintain the anonymity of participants. Records of the interviews identified participants only by their pseudonyms. Additionally, the researcher showed genuine respect and appeared to represent no threat to the informants, which helped in gaining their trust. Because of the potentially sensitive nature of the topic, the researcher first asked general questions about respondent's views on the current phenomena, and when the informants felt relaxed, asked more specific questions regarding their travel. Both rounds interviews lasted from 45 minutes to one hour on average. The interviews were not tape-recorded, as a number of informants explicitly expressed their anxiety of being taped because of the sensitive nature of this study. Overall, the interviews generated 102 pages of notes.

In both rounds of interviews, interviewing continued until theoretical saturation was reached. That is, the data no longer supported the existence of new conceptual categories or category properties (Glasser \& Strauss, 1967). As Burrell and Morgan (1979) have noted, meanings are socially constructed while knowledge is negotiated within cultural settings and relationships with people. Based on this understanding, the lead author engaged in dialogue 
with the informants while he immersed himself in the social setting thereby enabling the researcher to investigate aspects of respondents' views that reveal aspects of the fundamental meaning that underlies their individual and collective social understandings (Burrell \& Morgan, 1979). The researchers were able to build an understanding of contemporary Chinese culture and associated political views and use this as a platform to explain the underlying social phenomenon and associated themes. A standard thematic analysis was undertaken to analyze transcripts. We began the coding process by developing in-vivo codes in Chinese, and similar codes were then organized into higher-level themes. The interpretation of the findings was then expanded and refined. The themes were then translated into English. The quotes in the study are illustrative and representative examples that were common across the data set. The researchers found that themes emerging from the dataset were related to theories or concepts of, for example, social identity theory (Gries, 2006) and imagined communities (Anderson, 1983). The following discussion is supported by direct quotes, which reflect the voice of participants and supports findings (Creswell, 2007; Krueger \& Casey, 2009). Following Kruger \& Casey's (2009) advice, three quotes for each theme category was adopted to build a comprehensive understanding of the views of respondents.

While informants were advised that their identities would remain anonymous, some responses may have been influenced by the sensitive nature of the study. It was not possible to estimate the degree to which this may have occurred. It is also important to note that some of the stories may have been "well-rehearsed" to provide a "proper socially acceptable answer". Occasionally, as an insider, the lead researcher felt emotionally attached to the way in which informants expressed their feelings. As such, the stories may have been influenced by the occasional questions asked by the researcher when the researcher sensed a hesitant attitude or conflicting statements from the informants. However, this does not make these stories less meaningful as these stories help to explore the "deeper meaning of events" 
through the voices of the informants (Gudmundsdottir, 2006). Although there may be a degree of bias, the process allows the study to achieve a richness and depth that a non-native Mainland researcher may not be able to achieve as Denzin and Lincoln (2003) suggested.

\section{Results}

\section{Political incident as a catalyst in triggering Chinese popular nationalism}

It became apparent during the study that Chinese popular nationalism does influence Chinese outbound tourism. Eighteen of the 25 informants explicitly commented that they could be described as people who exhibited nationalist sentiments towards China and any actions against their group would be considered as improper. As one informant explained, "I understand what is important, and I am Chinese. So I do not want to stand on the wrong side, and be seen as someone who does not love my country?" Another informant stated "I am afraid if I go there (Japan), then someone will take a picture of me and state that I don't like my country." (Peter, M, 28). Another 42 year old informant added that "I do not want to say I am a nationalist. But travelling at this particular moment does not seem a wise choice both for my personal interests and my social life" (Wendy, F). This response reflects the view (Zhao, 2000) that many Chinese people recognise the importance of their national identity at a whole of society level and then they relate this to themselves at an individual level. On this basis, findings of this study shows that rising Chinese popular nationalism complicates the political situation in the grassroots community of China and explains why the Chinese public have a propensity to refrain from travelling to a tourism destination during periods of tension (e.g. Japan). For this reason it is apparent that popular nationalism can have a serious effect on tourism destinations that are in dispute with China.

Most informants reported that the most frequent information they heard about the event was via the media and in general discussions. This information was usually framed in a 
nationalistic tone that focused on the view that "Japan is still against us." As one informant stated, "the regular political movements of the Japanese government did not make me feel that they acknowledge the past" (Tom, 31, M). Another informant further explained, "although I do not care about politics, I am still Chinese. I have grown up with the issues concerning Japan and China. When this incident happened, all the things happened before just popped into mind" (Silvia, 27, F). This view was reinforces by another informant who stated "well, I believe Japanese people are nice. But when you hear bad sides of it [Japan] many times, it just makes you feel bad about Japan.” (Jennifer, 27, F). These messages convey a nationalist sentiment, which encourages the Chinese public to view Japan as a potential enemy. This situation is amplified by the Chinese media and nationalism activists who are keen to publicize any mishap related to Japan because it rouses Chinese nationalist sentiments and reaches a larger audience (Wang, 2006). It regularly reminds Chinese of China's uneasy history with Japan and is interpreted as a sign that the Japanese government appears to be trying to suppress China. Moreover, it helps to unite the nation and strengthens the Chinese public's collective power against Japan. The Diaoyu/Senkaku island dispute exemplifies how incidents in China's political relations with other countries can easily provoke a strong backlash against a particular tourism destination.

\section{Short term impact}

When the nation's interest is perceived to be at stake or is threatened by foreigners, the Chinese public has a significant propensity to react negatively. In this case action was on a personal level through either cancellation or delay of travel. During the period of tension many Chinese also refrained from purchasing Japanese consumer goods as another form of protest. This practice was perceived by informants to be effective due to China's economic power. In this case, Japanese nationalists visiting the Diaoyu/Senkaku island were regarded by informants as an issue of national importance as they perceived that Chinas' dignity was at 
stake, and the purpose of the collective response was to teach the Japanese government a lesson that China cannot be bullied. As one of the informants explicitly stated "I understand a lot of us do this as perhaps a way to let them [Japanese government] understand China is not the China of 20 years ago, and we are now a country with great economic power" (Tony, 41 , M). This view was reiterated by Jason $(23, \mathrm{M})$ who explained, "I like Japanese brands and traveling to Japan, but the thing is that they [Japan] should understand only peace with China contributes to the future of Japan. Clearly, we are the second strongest economy in the world." Another informant added "I was feeling so unconformable when I ate in a Japanese restaurant the other day. Why should I make economical contributions to our unfriendly friend to help them build up their economy against us?" (Jennifer, 27, F). This finding is in line with previous studies that the reactive nature of Chinese popular nationalism not only exists in the political space but also is expressed as anti-foreign sentiments in economic arenas (Huges, 2006), such as abandoning visits to Japan.

Significantly, a number of the informants also mentioned that their companies advised them to refrain from travelling to Japan during the island dispute. As one of the informants stated "my company sent out an email to every staff saying, please do not associate yourself with this political incident" (Andrew, 29, M). Another informant pointed out "the thing is that travel agencies seldom refund your trip. But this time, they refunded my booking fee. You know, you could not separate this with the government" (Simone, 35, F). Thirty-five year old Cameron explained, “we have planned to travel to Japan for our company's annual incentive travel. Then suddenly, the management told everyone that travel agencies are concerned with our safety and our trip needs to be delayed. Well, really?" and he smiled (M). These companies were mostly state-owned enterprises. This incident shows that the issue goes beyond the grassroots level. Thus, Chinese popular nationalism is also manifested in a collective way that exerts pressure on the Chinese government and its agencies to reconsider 
their current stand towards previously hostile countries, such as the message of discouragement from the state owned enterprise reported above.

\section{Long term impact}

However, their negative travel intentions towards Japan had changed significantly when the lead researcher interviewed the informants three months later, by which time tensions had subsided. Out of 25 informants, sixteen had resumed their travel plans to Japan in early 2013 and the other nine also expressed a desire to travel to Japan at a later stage. "Actually, I am planning to visit Japan during Chinese New Year. You know, the incident is not as severe as before. Also, not many people care about it now" (Simone, 35, F). Jennifer $(27, F)$ also pointed out "you know many travel agencies have already started their tours to Japan. So I might join them as well.” Another informant expressed his desire to Japan by saying that "my colleagues went there two weeks ago and they told me it [their trip in Japan] was fantastic. No safety issue there. Apparently, there is no issue traveling to Japan in my company. So why should I not go there?" (Christine, F, 38). Though there are a number of reasons why they resumed their travel plans, time appears to be a significant variable in respect to the impact of popular nationalism. That is, its direct impact lasted only for a short period but was clearly effective in constraining Chinese tourists' outbound travel. However, the informants also admitted that if the same political incident reoccurred, they would probably cancel their travel plans to Japan. This indicates that although the apparent impact is time dependent it can easily rebound, because of real or perceived damage to China's national identity. As Gao (2012, p. 187) observed, contentious actions by the Japanese government has helped 'unite otherwise disconnected individual consumers into emotionally charged, well-organized activists' and resulted in increased anti-Japanese sentiments.'

\section{Themes}


Three main themes emerged from the research and are outlined in Table 2. Each theme provides insights into the views and actions of the participants. These themes are:

1. A political incident that acts as a catalyst for growth of popular nationalism. The incident demonstrated the ability of a political dispute such as the Diaoyu/Senkaku islands to influence Chinese outbound travel through the effect it had on Chinese nationalism. Given other recent disputes with neighbouring countries such as Vietnam this aspect of Chinese nationalism can be regarded as a general condition of Chinese life, not just a factor that is restricted to Japan. This observation is important and parallels recent findings by Prideaux and Tse (2015).

2. The grassroots nature of travel constraints. The grassroots nature of popular Chinese nationalism can be directed upward to affect national policy. This form of nationalism is a strong driver in individual decision making as to which destinations are seen as acceptable to visit by colleagues and friends.

3. The role of state travel constraints. Decisions by the state to direct personal travel decisions may be both bottom-up and top-down. In the case of bottom-up, the state is able to influence the decision making of individuals through state owned media and companies. In turn, popular opinions may sometimes influence policy based on how the collective voice of the nation responds to various incidents. This may be aided by the ability of the state to influence the media through its ownership of the media. Top-down decisions may also be influenced by foreign and in some cases domestic policy considerations and usually in the form of state direction over tourists' decisions.

Table 2: Themes identified 
Political incident as a I have cancelled my travel plan to Japan and will not visit Japan at least catalyst for the these two months. At the moment, seemingly, everyone is against Japan. break- out of popular nationalism The media brings up the historical issues with Japan, such as the invasion in second war... It is kinda of making everyone's patriotic sentiments influencing Chinese tourist from group stronger...Well, I do not care about politics but this (patriotic sentiments) makes me a bit uncomfortable, as I am still Chinese. At a personal level, I level to individual level feel like that if I go there, my colleague and friends will think I am kinda of against the Chinese public and feel like I am traitor (卖国贼). To me, I am afraid if I go there, then someone will take a picture of me and state that you don't like your country (Peter, 28, M)

Grassroots travel constraints

State travel constraints
I do think it is the accumulating national sentiments made me think twice and delayed my travel plan...Well, I am still considering it but the thing is that every time it (the political incident) happens, I guess we will have no choices. This kind of influence is quite time dependent... Because looking at the current situation now, I feel like every time this happens, it will stimulate a group of nationalists and it reminds me of all the things before. The incident will go away soon, but when it happens, it (the nationalist sentiments) comes up again. For me, personally, I do not hate Japan. I mean it is a beautiful tourist destination but I just feel a bit weird if I go there at this time and perhaps in the future (Vanessa, 37, F)

Personally, I might go there next year when the situation becomes less severe. The other day, our company (managers) sent out an email to every staff saying; please do not associate yourself with this political incident. I mean.... my company did this because my boss does not want our company to be in the nationalism spotlight. It will not be good for our reputation. I mean thinking of this, people's nationalism sentiments are so high at this moment, and the government I think will somehow listen to the voices. Actually, I was so amazed for this incident that how firmly the government stands out. This made me think of the case of the Philippines. You know when the government issued travel warning, who will go there! (Andrew, $29, \mathrm{M})$ 


\section{Research Model}

To illustrate the forces of nationalism described earlier, an explanatory model (Figure 1) was developed to show the various relationships involved. This approach to model building is based on Getz's (1986) typology of models that proposed two classes of tourism models: a descriptive or theoretical class of model that can be used to reduce a wide range of potential variables into a set of manageable relationships able to be used to describe and explain various aspects of the tourism system, and an operational class of models able to be used for planning purposes. The model proposed in Figure 1 falls into Getz's first class of model types. From a theoretical perspective, the model is underpinned by several research streams pertaining to tourist decision-making and destination choice (Crompton, 1992; Um \& Crompton, 1990; Woodside \& Lysonski, 1989), travel constraints (Nyaupane \& Andereck, 2008; Pennington-Gray \& Kerstetter, 2002), and nationalism (Gries, 2006; Huges, 2006; Zhao, 2005) as detailed above.

The right side of Figure 1 illustrates in the causes of popular nationalism. Chinese popular nationalism, as a grassroots political ideology (Gries, 2006), is usually triggered by a catalyst such as a political incident (the Diaoyu/Senkaku island dispute for example). Although issues related to domestic and international politics is seldom mentioned in the travel literature, this factor plays a role in influencing the tourists' initial consideration set of destination choice and manifests as a critical source of travel constraint. Yet, the duality of this factor goes beyond existing knowledge and understanding from travel constraint and destination choice theories which offer connation to individual-level behaviors. Results of the study, however, show that reaction to the catalyst incident occurs at two levels: the group or societal level and the individual level. At the group or societal level the event is reported through the media which generates discussion and interpretation of the incident through a 
series of lens and filters that focus on reinterpretation of past history; where the incident occurred and what special meaning this may have; and cultural conflicts. This level of discussion occurs at a broad societal level with an emphasis on the role of the individual as part of the group. Collectively these factors generate the emergence of popular nationalism. At the individual level, the influence of reference groups, personal safety concerns and social pressure encourages individual to support ideas that have emerged at the group level as popular nationalism. This is vividly reflected in Jason's (23) account "I am generally okay for travelling to Japan. But once this incident happened, we could hear tons of news talking about this, which were framed in a nationalist tone. Then my friends around talked about it and some of them stopped buying Japanese products and going to Japanese restaurants. Some said it would be risky to travel to Japan because of the anti-Japan sentiments. Well, you know Chinese society is quite collective. So... I mean it is hard not to follow."

The middle section of the model illustrates the short term and long term impacts of Chinese popular nationalism. As the perceived severity of the incident increases, two types of travel constraints based on popular nationalism emerge: a grassroots travel constraint and a state level travel constraint. Each type of constraint has impacts based on the strength of "symbolic values" associated with the catalyst incident such as past history. In most cases, popular nationalism is initiated at the grassroots level (e.g. delaying personal travel plans) and as the severity of the incident accelerates, it starts to push through to the state level (e.g. China's state owned enterprises). Where the state elects to accommodate popular nationalism (e.g., messages of discouragement from government agencies) government action is able to further strengthen the collective power of the grassroots response through state travel constraints. This is reflected in Tony's account (41) "I think the severity of the incident does not depend on the reality but more than how important it looks like for us. Also, if you noticed that ten years ago, the government sort of was the leading one in this incident but 
now, things changed, the grassroots people like us are more powerful and I do think the government is listening to us." These points are also observed in the study of Gries, Steiger, and Wang (2015).

As a consequence, these travel constraints reinforce tourists' negative attitudes toward Japan and hence, their late consideration (evoked) set of destination choice is altered based on the severity of the incident and their attitudes and behaviors. Hence tourist destination selection decisions are therefore taken in compliance to personal beliefs and social norms. Such actions then manifest through economic counterattack (the right side of the model). In China, abandoning travel plans is a common response to issues related to popular nationalism.

An analysis of Chinese outbound travel data indicates that although Chinese enjoy travelling to Japan in part because of proximity and favorable currency as well as other pull motivational factors (Tan, 2015), they continue to have mixed feelings and attitudes towards Japan. For example, "I have to say I really wanted to go to Japan, because it is close by and cheaper to travel there now. Also, I love shopping and the culture in Japan. But you know, this incident made me feel really bad. I mean [I am] just not sure why Japanese government are not working towards a peaceful relationship between these two countries" (Jennifer, 26). This and similar quotes from other respondents demonstrates how feelings of nationalism may be more important in destination selection than personal beliefs during a time of political tension.

The data in this study shows that although these apparent impacts occurred within a short-term period, the long-term impacts were also implicitly generated at both grassroots level (e.g. a collective negative attitude towards Japan) and state level (e.g. foreign travel 
policies towards Japan). The combined effects of such elements make the popular nationalism phenomenon particularly disruptive and reactive for Chinese outbound tourism.

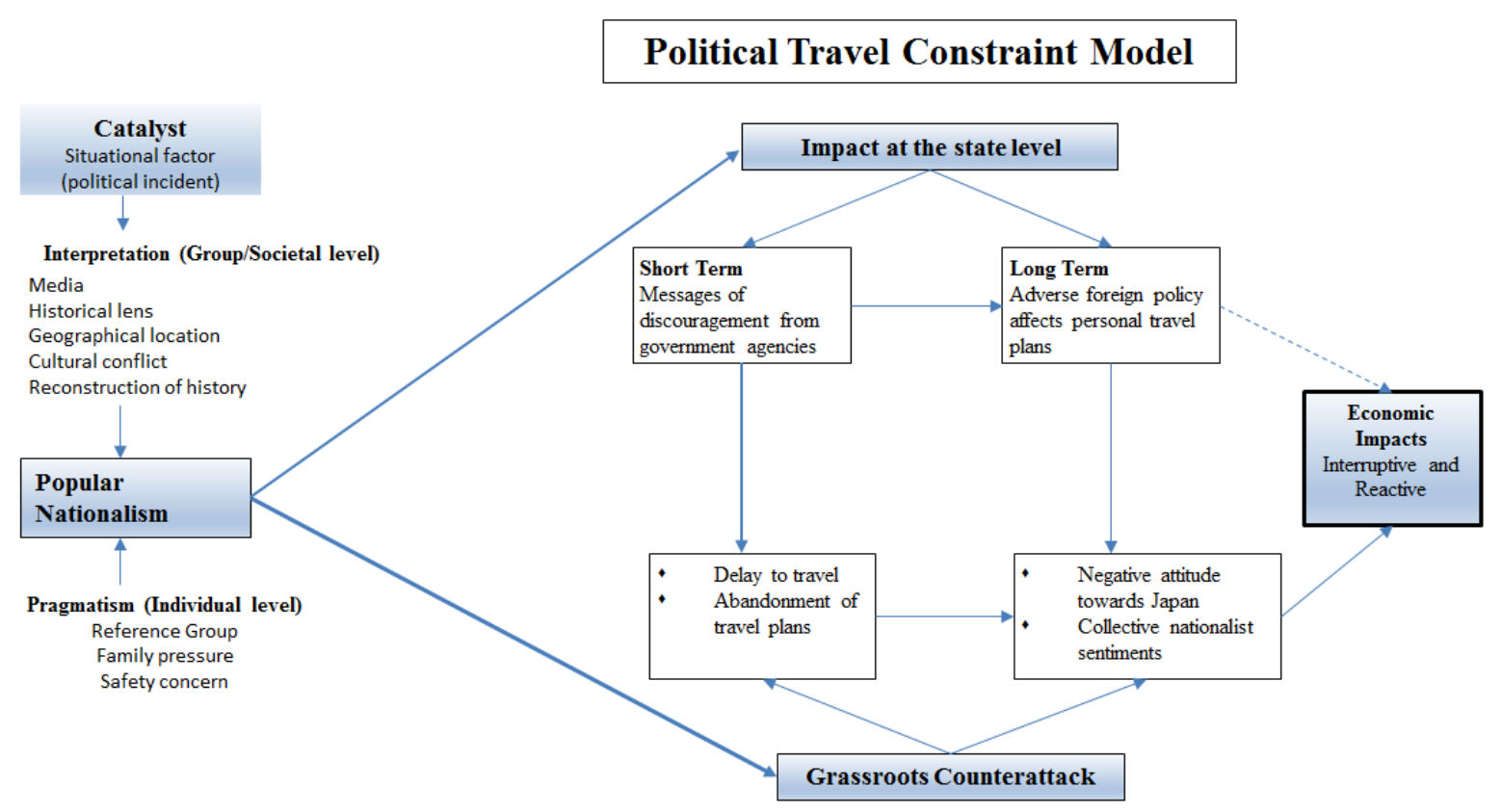

Figure 1: Political Travel Constraint Model

\section{Discussion}

This research has demonstrated the potential for Chinese tourists to be explicitly and negatively influenced by Chinese popular nationalism in their attitudes and travel intentions towards countries that have been hostile in the past, Japan for example. Although this travel constraint has identified only recently in a tourism setting, it is very likely that it may have occurred in various forms towards other nations. The impact of Chinese popular nationalism fuelled by a political incident, like the Diaoyu/Senkaku Island incident, is sporadic and appears to have only a short-term impact. However, it may also be disruptive and lead to counter measures by foreign governments as well as companies that suffer economic loss through travel cancellations. Beyond this short impact, the long-term effects of Chinese popular nationalism may at worst lead to a situation described by Gao (2012, p.184) as 
incidents that generate 'a self-feeding cycle of anti-foreign sentiments' where the Chinese public look for other avenues to express views.

Given the collective nature of Chinese society, an observation based on Hofstede's (2001) pioneering work about the nature of societies, it is not surprising that in China the needs of the nation rather than of the individual are seen as paramount, particularly when there is a perception that the nation's interests are threatened. For this reason, when the nation's interest is at stake, Chinese have a propensity to unify and collectively refrain from or even boycott travel to countries that are involved in a dispute with China. Given that Chinese culture ranks high in conflict avoidance it is also not surprising that Chinese tourists are likely to avoid directly confronting issues and controversies of this type and in the case of Japan decide not to travel there as a way of avoiding conflicts at a personal level as well as conforming to the social norm.

Because of Chinese popular nationalism's collective grassroots power, it has emerged as a challenging force that can shape the geopolitical environment of Chinese outbound tourism in contemporary China. For this reason, tourism destinations in a bilateral relationship with China should be aware of the possible disruptive nature of political incidents particularly those that can be used by Chinese nationalists to stoke nationalist fury towards the destination. The model suggested in Figure 1 illustrates the processes involved and the type of outcomes that may be expected.

\section{Conclusion}

When first published, Crawford and Godbey's (1987) model on the three dimensions of leisure constraints had a significant impact on the understanding of factors that constrain travel activities. This research has added a new dimension to the model by identifying a 
previously poorly understood class of political travel constraint that in the Chinese context differs from Western centric views on how citizens react to political conflicts. The paper also responds to a call by Dong and Chick (2012) for future empirical research that goes beyond the Western paradigm in constraint literature. While the intent of this study is not to categories Chinese popular nationalism into the existing three hierarchical travel constraint model, it does suggest that there is another layer of complexity that needs to be recognized when the travel constraint model is applied to assess relations between previous hostile countries such as Japan and China. More importantly, it is the first attempt to model the processes and factors associated with political travel constraints through popular nationalism. From this perspective, this highlights the need to incorporate cross-cultural factors into the travel constraint literature. It also highlights the need for researchers, and practitioners, to be alert to the potential adverse impacts of political disputes on bilateral tourist flows.

From a border theoretical perspective, this study extends the literature on anti-consumption and political consumerism by investigating the effect of a social phenomenon on travel rather than on brands and products. Hence, it goes beyond the current understanding about brand and product rejection and boycott (Lee et al., 2009; Yuksel \& Mryteza, 2009) by suggesting that these theories can be extended to a tourism context. In this way the study bridges a research gap by developing new understanding on the tourist decision making process. Travel becomes a means and an agenda for political negotiations. Based on the findings reported above, such a process involves impacts from both the state (and societal) level and the grassroots (individual) level with both long and short term adverse effects and consequences. More importantly, this study enriches the existing understanding of political consumerism in that tourists decisions on avoiding travelling to a specific destination goes beyond the consideration of the factors identified by Micheletti and Stolle (2006, p. 2) as 'justice, fairness, and non-economic issues that concern personal and family well-being 
and ethical or political assessment of favorable and unfavorable business and government practice'. The findings also show that travel related political consumerism in China has far greater socio-cultural influences and implications than previously recognized. Not only did the central and municipal governments play a role in reinforcing the avoidance attitude and behaviors, the community, organizations, and the family may also play a role.

Further, this research highlights the interdependent nature of popular nationalism and state nationalism in the Chinese context. As demonstrated in the model, the increasing pressure of popular nationalism has some potential to push the Chinese government to toughen its foreign policy to maintain its legitimacy (Gries et al., 2015). This in turn strengthens the power of Chinese popular nationalism. These observations challenge the current debate on international relations (IR) bargaining theory, which argues that Chinas international policy is based on strategic interests rather than the views that have emerged through popular nationalism (Weiss, 2013). To the best knowledge of the researchers, this research is the first attempt in the tourism literature to highlight the dual relationship between state and popular nationalism that co-shapes China' foreign policy (e.g. travel policy) as well as the grassroots response of Chinese citizens that is expressed through cancellation of trips. Moreover, the study is an illustration of Putmans (1988) "two-level games". In this study, we find that Chinese nationalism may be better conceptualized as a flow shifting from the grassroots level to state level and vice versa. Flows of this nature, which have inputs from these two sources, co-shape the geo-political environment at both policy and grassroots level.

This research suggests that policy makers and tourism practitioners in countries that enjoy a bilateral travel relationship with China need to be aware of the potential impact of popular nationalism in both the short and long terms. During the island dispute period, it is important for Japan tourism service providers to keep a low profile instead of actively promoting Japan as a tourist destination. For example, with respect to Japanese tourism 
service providers targeting at Chinese tourists, they need exhibit additional caution in designing and executing their destination marketing campaigns, as any improper marketing campaign would potentially trigger popular nationalism reactions against their tourism products (Li, 2009). For Chinese tourism service providers, they should also exert caution whether they should blindly follow the trend against traveling to Japan by showing support, as a nationalist goal is not necessarily shared (Li, 2009), particularly some respondents in this study explicitly expressed that they regarded these companies to manipulate public sentiments to increase their commercial value rather than offer genuine support. Additionally, a large number of the respondents' their travel intention towards Japan changed after this island dispute, which indicates the popularity of Japan as a tourist destination. At the same time, they also expressed their future concerns. As pointed by one of the reviewers, it is important to understand this mixed feeling of Chinese tourists, with both hatred and love, towards Japan and how destinations could better help Chinese tourists negotiate their political travel constraints to facilitate their love relationship with the destination. Additionally, such frameworks could be used to understand tourist flow between China and Vietnam or the Philippines to reflect the emergent identities of Chinese popular nationalism in the process of the transition happening in China today.

While this research focused on Chinese/Japanese bilateral flows, similar problems in bilateral relations exist between other nations that have experienced political dispute, such as Korean and Japan. In the case of Japan and Korea, nationalism can be identified as one of the underlying factors in the emergence of disputes that lead to a fall in tourist flows (Kim \& Prideaux, 2012). As such, future research taking political context of the selected countries beyond China into consideration could expand the proposed research framework by exploring its manifestations in other tourism destinations. Additionally, further longitudinal research is required to examine how changes to variables such as exchange rate may affect various 
elements of the framework. As such, our research has presented a small step in this larger endeavor to uncover the complexity of nationalism in tourism 


\section{References}

Aldrich, J. H., Gelpi, C., Feaver, P., Reifler, J., \& Sharp, K. T. (2006). Foreign policy and the electoral connection. Annu. Rev. Polit. Sci., 9, 477-502.

Alvarez, M. D., \& Campo, S. (2014). The influence of political conflicts on country image and intention to visit: A study of Israel's image. Tourism Management, 40, 70-78.

Anderson, B. (1983). Imagined comnunities: reflections on the origin and spread of nationalism. New York: Courier.

Birkland, T. A. (1997). After Disaster: Agenda Setting, Public Policy and Focusing Events. Washington, DC: Georgetown Univesity Press.

Burrell, G., \& Morgan, G. (1979). Sociology Paradigm and Organisational Analysis: Elements of the Sociology of Corporate Life. Portsmouth: Heinemann.

Chen, H.-J., Chen, P.-J., \& Okumus, F. (2013). The relationship between travel constraints and destination image: A case study of Brunei. Tourism Management, 35, 198-208. doi: 10.1016/j.tourman.2012.07.004

Cheng, M., \& Wong, A. I. (2014). Tourism and Chinese popular nationalism. Journal of Tourism and Cultural Change, 12(4), 307-319.

Cho, M., Bonn, M. A., \& Brymer, R. A. (2014). A Constraint-Based Approach to Wine Tourism Market Segmentation. Journal of Hospitality \& Tourism Research. doi: 10.1177/1096348014538049

Crawford, D. W., \& Godbey, G. (1987). Reconceptualizing barriers to family leisure. Leisure Sciences, 9(2), 119-127.

Crawford, D. W., Jackson, E. L., \& Godbey, G. (1991). A hierarchical model of leisure constraints. Leisure Sciences, 13(4), 309-320.

Crompton, J. L. (1979). Motivations of pleasure vacation. Annals of Tourism Research, 6, 408-424.

Crompton, J. L. (1992). Structure of vacation destination choice sets. Annals of Tourism Research, 19(3), 420-434.

Cui, S. (2012). Problems of Nationalism and Historical Memory in China's Relations with Japan. Journal of Historical Sociology, 25(2), 199-222. doi: 10.1111/j.1467-6443.2011.01419.x

Denzin, N. K., \& Lincoln, Y. S. (2003). Introduction: The discipline and practice of qualitative research. In N. K. Denzin \& Y. S. Lincoln (Eds.), The landscape of qualitative research: Theories and issues (2nd ed., pp. 1-46). Thousand Oaks, CA: Sage Publications.

Dong, E., \& Chick, G. (2012). Leisure Constraints in Six Chinese Cities. Leisure Sciences, 34(5), 417-435. doi: 10.1080/01490400.2012.714702

Eisenhardt, K. M. (1989). Building theories from case study research. Academy of Management Review, 14(4), 532-550.

Fendt, L. S., \& Wilson, E. (2012). 'I just push through the barriers because I live for surfing': how women negotiate their constraints to surf tourism. Annals of Leisure Research, 15(1), 4-18.

Gao, Z. (2012). Chinese Grassroots Nationalism and Its Impact on Foreign Brands. Journal of Macromarketing, 32(2), 181-192. doi: 10.1177/0276146711428808

Getz, D. (1986). Models in tourism planning: Towards integration of theory and practice. Tourism Management, 7(1), 21-32.

Glasser, B. G., \& Strauss, A. L. (1967). The Discovery of Grounded Theory: Strategies for Qualitative Research. Hawthorne, NY: Aldine de Gruyter.

Gries, P. (2006). China and Chinese Nationalism. In G. Delanty, Krishan (Ed.), The SAGE Handbook of Nations and Nationalism. London: SAGE.

Gries, P. H., Steiger, D., \& Wang, T. (2015). Popular Nationalism and China's Japan Policy: the Diaoyu Islands protests, 2012-2013. Journal of Contemporary China, 1-13.

Gudmundsdottir, S. (2006). The teller, the tale and the one being told: the narrative nature of the research interview. In P. Atkinson \& S. Delamont (Eds.), Narrative Methods, Volume II, Narrative Applications (pp. 220-234). London: Sage 
He, L., Li, X., Harrill, R., \& Cardon, P. W. (2014). Examining Japanese tourists' US-bound travel constraints. Current Issues in Tourism, 17(8), 705-722.

Hubbard, J., \& Mannell, R. C. (2001). Testing competing models of the leisure constraint negotiation process in a corporate employee recreation setting. Leisure Sciences, 23(3), 145-163.

Huberman, A. (2003). Qualitative data analysis: an expanded sourcebook. New York: Sage Publication.

Huges, C. (2006). Chinese Nationalism in the Global Era. London: Routledge.

Hung, K., \& Petrick, F. (2010). Developing a measurement scale for constraints to cruising. Annals of Tourism Research, 37(1), 206-228.

Ishii, K. (2013). Nationalism and preferences for domestic and foreign animation programmes in China. International Communication Gazette, 75(2), 225-245. doi: $10.1177 / 1748048512459148$

Iso-Aloha, S. E. (1982). Toward a social psychological theory of tourism motivation: A rejoinder. Annals of Tourism Research, 9(2), 256-261.

Japan National Tourism Organization. (2014). Tourism Statistics. Retrieved 10 November, 2014, from http://www.jnto.go.jp/eng/ttp/sta/

Karl, M., Reintinger, C., \& Schmude, J. (2015). Reject or select: Mapping destination choice. Annals of Tourism Research, 54, 48-64. doi: 10.1016/j.annals.2015.06.003

Kedourie, E. (1993). Nationalism (4th ed.). Oxford: Blackwell.

Kelman, H. C. (1997). Nationalism, patriotism, and national identity: Social-psychological dimensions. In D. Bar-Tal \& E. Staub (Eds.), Patriotism in the life of individuals and nations. Chicago: Nelson-Hall.

Kim, S., \& Prideaux, B. (2012). A Post-Colonial Analysis of Bilateral Tourism Flows: the Case of Korea and Japan. International Journal of Tourism Research, 14(6), 586-600. doi: 10.1002/jtr.859

Lai, C., Li, X., \& Harrill, R. (2013). Chinese outbound tourists' perceived constraints to visiting the United States. Tourism Management, 37, 136-146. doi: 10.1016/j.tourman.2013.01.014

Lee, B. K., Agarwal, S., \& Kim, H. J. (2012). Influences of travel constraints on the people with disabilities' intention to travel: An application of Seligman's helplessness theory. Tourism Management, 33(3), 569-579. doi: 10.1016/j.tourman.2011.06.011

Lee, M. S. W., Motion, J., \& Conroy, D. (2009). Anti-consumption and brand avoidance. Journal of Business Research, 62(2), 169-180. doi: 10.1016/j.jbusres.2008.01.024

Li, H. (2009). Marketing Japanese Products in the Context of Chinese Nationalism. Critical Studies in Media Communication, 26(5), 435-456. doi: 10.1080/15295030903325339

Li, J., \& He, H. (2012). Anti-Japan protests turn violent in Shenzhen, Guangzhou and Qingdao, South China Morning Post. Retrieved from

http://www.scmp.com/news/china/article/1038664/anti-japan-protests-turn-violent-shenzh en-guangzhou-and-qingdao

Li, M., Zhang, H., Mao, I., \& Deng, C. (2011). Segmenting Chinese Outbound Tourists by Perceived Constraints. Journal of Travel \& Tourism Marketing, 28(6), 629-643. doi: 10.1080/10548408.2011.598747

Mannell, R. C., Iwasaki, Y., \& Jackson, E. (2005). Advancing quantitative research on social cognitive theories of the constraint-negotiation process. In E. L. Jackson (Ed.), Constraints to leisure (pp. 261-275). Pennsylvania: Venture Publishing.

Matthews, H. G., \& Richter, L. K. (1991). Political science and tourism. Annals of Tourism Research, 18(1), 120-135.

Micheletti, M., \& Stolle, D. (2006). Politics, Products, and Markets: Exploring Political Consumerism. New Brunwinsk, NJ: Transaction Press.

Ministry of Foreign Affairs of the People's Republic of China. (2012). Chinese and foreign media briefing of Vice Foreign Minister Zhang Zhijun on the Diaoyu Islands issue. Retrieved October 5, 2014, from http://www.fmprc.gov.cn/mfa chn/zyxw 602251/t973094.shtml 
Nyaupane, G. P., \& Andereck, K. L. (2008). Understanding travel constraints: Application and extension of a leisure constraints model. Journal of Travel Research, 46(4), 433-439. doi: $10.1177 / 0047287507308325$

Pearce, P. L., \& Lee, U.-I. (2005). Developing the travel career approach to tourist motivation. Journal of Travel Research, 43(3), 226-237.

Pennington-Gray, L. A., \& Kerstetter, D. L. (2002). Testing a constraints model within the context of nature-based tourism. Journal of Travel Research, 40(4), 416-423.

Philippines Department of Tourism. (2015). Visitor Arrivals to the Philippines by Country of Residence. Retrieved 10 June, 2015, from http://e-services.tourism.gov.ph:8080/Report/Public\%20Pages/DDownloadables copy(1).as $\underline{\mathrm{px}}$

Prideaux, B. (2005). Factors affecting bilateral tourism flows. Annals of Tourism Research, 32(3), 780-801.

Prideaux, B., \& Tse, T. (2015). Growth of Chinese Tourists to Hong Kong, China, 2002 to 2014 Implications and Way Forward. United Nations World Tourism Organisation, Knowledge Network Issues Paper Series, 1(1), 2411-4170.

Putnam, R. D. (1988). Diplomacy and domestic politics: the logic of two-level games. International organization, 42(03), 427-460.

Smith, A. D. (2001). Nationalism: Theory, Ideology, History (1st ed.). Oxford: Blackwell.

South China Morning Post. (2012, September 18 ). Timeline: the Diaoyu-Senkaku Islands dispute. Retrieved from http://www.scmp.com/news/china/article/1039204/timeline-diaoyu-senkaku-islands-disput $\underline{\mathrm{e}}$

Sparks, B., \& Pan, G. W. (2009). Chinese Outbound tourists: Understanding their attitudes, constraints and use of information sources. Tourism Management, 30(4), 483-494. doi: 10.1016/j.tourman.2008.10.014

Spegele, B., \& Nakamichi, T. (2012). Anti-Japan Protests Mount in China, The Wall Street Journal. Retrieved from http://www.wsj.com/articles/SB10000872396390443720204578000092842756154

Strauss, A., \& Corbin, J. (1990). Basics of qualitative research: Grounded theory procedures and techniques. Newbury Park: Sage.

Tan, H. (2015). China tourists, weaker yen drive tourist inflows higher in Japan. Retrieved Dec 21, 2015, from

http://www.cnbc.com/2015/12/20/china-tourists-weaker-yen-drive-tourist-inflows-higher-i n-japan.html

Tang, W., \& Darr, B. (2012). Chinese Nationalism and its Political and Social Origins. Journal of Contemporary China, 21(77), 811-826.

Tian, S., \& Pasadeos, Y. (2012). A Revised Model of Animosity: The Impact of Anti-Japanese Sentiment on Consumer Behavior in China. Journal of Current Issues \& Research in Advertising, 33(2), 170-191. doi: 10.1080/10641734.2012.700627

Timothy, D. J., \& Kim, S. (2015). Understanding the tourism relationships between South Korea and China: a review of influential factors. Current Issues in Tourism, 18(5), 413-432.

Tse, T. S. M. (2013). Chinese Outbound Tourism as a Form of Diplomacy. Tourism Planning \& Development, 1-10. doi: 10.1080/21568316.2013.783738

Um, S., \& Crompton, J. L. (1990). Attitude determinants in tourism destination choice. Annals of Tourism Research, 17, 432-448.

Wang, J. (2006). The Politics of Goods: A Case Study of Consumer Nationalism and Media Discourse in Contemporary China. Asian Journal of Communication, 16(2), 187-206. doi: 10.1080/01292980600638710

Weiss, J. C. (2013). Authoritarian signaling, mass audiences, and nationalist protest in China. International organization, 67(1), 1-35. 
Woodside, A. G., \& Lysonski, S. (1989). A general model of traveler destination choice. Journal of Travel Research, 27, 8-14.

Woodside, A. G., Macdonald, R., \& Burford, M. (2004). Grounded theory of leisure travel. Journal of Travel \& Tourism Marketing, 17(1), 7-39. doi: 10.1300/J073v17n01_02

World Travel Online. (2012, June 6). More Shanghai residents visit Thailand, TTRweekly. Retrieved from http://news.travel168.net/focus on/20120606/29256.html

Yuksel, U., \& Mryteza, V. (2009). An evaluation of strategic responses to consumer boycotts. Journal of Business Research, 62(2), 248-259. doi: 10.1016/j.jbusres.2008.01.032

Zhang, H., Zhang, J., Cheng, S., Lu, S., \& Shi, C. (2012). Role of constraints in Chinese calligraphic landscape experience: An extension of a leisure constraints model. Tourism Management, 33(6), 1398-1407. doi: 10.1016/j.tourman.2012.01.001

Zhao, S. (2000). Chinese nationalism and its international orientations. Political Science Quarterly, 115(1), 1-33.

Zhao, S. (2004). A Nation-State By Construction: Dynamics of Modern Chinese Nationalism. California: Standford University Press.

Zhao, S. (2005). China's pragmatic nationalism: Is it manageable? The Washington Quarterly, 29(1), 131-144. doi: 10.1162/016366005774859670

Zhou, L., King, B., \& Turner, L. (1998). The China outbound market: An evaluation of key constraints and opportunities. Journal of Vacation Marketing, 4(2), 109-119. 